\title{
EXTRACTING SILVER FROM ANODE SLIME AFTER LEAD AND GOLD SEPARATIONS
}

\author{
EKSTRAKSI PERAK DARI LUMPUR ANODA SETELAH \\ PEMISAHAN TIMBAL DAN EMAS
}

\author{
ISYATUN RODLIYAH and SITI ROCHANI \\ Research \& Development Centre for Mineral and Coal Technology \\ Jalan Jenderal Sudirman 623 Bandung 40211 \\ Ph. (+6222) 6030483, Fax. (+6222) 6003373 \\ e-mail: isya@tekmira.esdm.go.id
}

\begin{abstract}
Anode slime, a byproduct from the process of copper electrorefining into the copper cathode, contains several valuable elements that can be extracted after $\mathrm{Cu}$ and $\mathrm{Pb}$ separations. Another alternative route for extracting the precious metals is still needed in terms of gaining more economical route. This research aims to seek the new route to extract the precious metals, especially silver from anode slime. In these experiments, the anode slime was obtained from PT Smelting Gresik. The lead was separated to produce the residue which was then chlorinated to extract the gold. Later the residue was used for extracting the silver by dissolving it in ammonium hydroxide solution with varying time dissolutions and concentrations and later dissolving in hydrochloric acid to form silver chloride which was reduced to metallic silver. These experiments had two trials. The first one related to directly using residual chlorination after gold separation and the second one employed the same residual chlorination but processed through de-chlorination by adding sodium carbonate. The result showed that the highest silver recovery of $53.56 \%$ related to $5 \mathrm{M}$ ammonium hydroxide concentration, the temperature of $30^{\circ} \mathrm{C}$, dissolution time of 60 minutes. Recovery of $53.78 \%$ was achieved at $7 \mathrm{M}$ ammonium hydroxide, the temperature of $30^{\circ} \mathrm{C}$, dissolution time of 60 minutes. The feed of those experiments came from direct residual chlorination, while chlorination residue that underwent de-chlorination produced silver recovery of $94.95 \%$ with leaching conditions of $5 \mathrm{M}$ ammonium hydroxide, the heating temperature of $30^{\circ} \mathrm{C}$ and leaching time of 60 minutes. The latest recovery was relatively high resulted in the process could be scaled up to a continuous system.
\end{abstract}

Keywords: anode slime, silver recovery, silver extraction, chlorination process.

\begin{abstract}
ABSTRAK
Sebagai hasil samping proses elektrorefining tembaga menjadi tembaga katoda, lumpur anoda yang mengandung unsur berharga ini dapat diekstrak setelah memisahkan tembaga dan timbalnya terlebih dahulu. Secara komersial, pemisahan logam berharga telah dilakukan, namun masih diperlukan rute alternatif yang lebih ekonomis. Penelitian ini bertujuan untuk mendapatkan rute baru dalam mengekstrak logam berharga terutama perak menggunakan lumpur anoda dari PT Smelting Gresik. Setelah dipisahkan timbalnya kemudian diklorinasi untuk memisahkan emasnya. Residu hasil klorinasi digunakan untuk ekstraksi perak dengan melarutkan residu dalam amonia dengan variabel konsentrasi dan waktu pelarutan, kemudian menambahkan asam klorida sehingga terbentuk perak klorida yang selanjutnya direduksi menjadi logam perak. Pada percobaan ini dilakukan dengan 2 cara yaitu residu klorinasi pemisahan emas langsung diekstraksi dengan $\mathrm{NH}_{4} \mathrm{OH}$ dan residu klorinasi yang sebelumnya diproses melalui deklorinasi dengan menambahkan natrium karbonat. Hasil percobaan menunjukkan perolehan perak tertinggi sebesar $53,56 \%$ pada $\mathrm{NH}_{4} \mathrm{OH} 5 \mathrm{M}$, suhu $30^{\circ} \mathrm{C}$, waktu pelarutan 60 menit dan perolehan sebesar $53,78 \%$ pada $\mathrm{NH}_{4} \mathrm{OH} 7 \mathrm{M}$, suhu $30^{\circ} \mathrm{C}$, waktu pelarutan 60 menit untuk residu langsung dari sisa klorinasi. Residu klorinasi yang diproses melalui deklorinasi terlebih dahulu sebelum dilarutkan dengan amoniak menghasilkan perolehan perak sebesar 94,95\%. Kondisi pelarutannya adalah $\mathrm{NH}_{4} \mathrm{OH} 5 \mathrm{M}$, suhu $30^{\circ} \mathrm{C}$, waktu pelarutan 60 menit. Perolehan yang relatif tinggi ini dapat ditingkatkan skalanya ke sistem kontinu.
\end{abstract}

Kata kunci: lumpur anoda, perolehan perak, ekstraksi perak, proses klorinasi 


\section{INTRODUCTION}

Anode slime is a byproduct of copper electrorefining process. It contains copper, lead, gold, silver, selenium, tellurium, arsenic, nickel, platinum, silica and other elements. In processing anode slime, extraction of precious metals becomes the main object, especially gold, silver, selenium, tellurium, and platinum. At the first stage, the study usually separates base metals content such as copper and lead into concentrate valuable elements. Gold and silver are then extracted followed by other precious metals.

Separating the precious metals from anode slime has been conducted commercially. According to Chen et al. (2015), the existing processes of anode slimes include pyrometallurgy (auto tech process), hydrometallurgy (Hoffman process) and hybrid processes that combine pyrometallurgy and hydrometallurgy technologies. The three technologies are based on the form and characteristics of silver and gold-copper anode slimes. However, many researchers are still searching alternatives for the more economical route. Many different solvents have been used such as sulphuric, chloride as well as nitric acids to separate the base metals which are dominated the anode slimes, then it follows by precious metals extraction. The study of silver extraction is a continuation of the previous studies (Rodliyah et al., 2011, 2013) to seek a new method using safer reagents, lower energy requirement and low investment as well as low operation cost.

Hydrometallurgical processing of anode slime from the refining of soldering scrap had been conducted by Harangi, Kulcsar and Kekesi (2015) in two steps. The first stage was leaching the anode slime by hydrochloric acid to remove the tin component. As silver is practically not dissolved in this nitric acid, tin can be leached from the residue by such a medium. Copper, which was not dissolved in the hydrochloric acid leaching step may also follow silver. Precious metals extraction had been accomplished by many researchers. (Hait et al., 2002; Hait, Jana and Sanyal, 2009) published a review of anode slime processing, including anode slime leaching by sulfuric acid. Research on gold, silver and copper separation had been accomplished by Bard and Sobral (2008) using hydrochloric acid solution adding sodium hypochlorite solutions as an oxidizing agent. The gold and silver can be separated from the slime after extracting the copper. His research was reinforced by Aktas (2010) who studied silver recovery from spent silver oxide button cell. Silver is selectively precipitated as silver chloride using potassium chloride solution, ensuring that other impurities remain in the solution. Silver chloride is subsequently reacted with metallic zinc powder in $1.0 \mathrm{M}$ $\mathrm{HCl}$ to yield metallic silver of $99.99 \%$ purity. Extraction of silver has already patented in the US Patent 3658510 A (Ernst Runyon G and E, 1972). In this study, the anode slime was dissolved in hydrochloric acid to produce silver chloride that could be separated from other metals. Wang et al. (1981) were recovered precious metals such as gold, silver, selenium, tellurium etc. from anode slime by the hydrometallurgical process. It is mentioned that to anode slime should be first leached by nitric acid at an elevated temperature in terms of obtaining a leach solution with $95 \%$ by weight of silver. The leachate silver nitric was then recovered in the form of silver chloride.

In contrast, the anode slime of PT Smelting Gresik commonly contains high lead, but another copper refining contains high copper. In this case, the copper should be separated before the precious metals as performed by Kilic, Kartal and Timur (2013). The anode slime was dissolved in sulfuric acid to separate copper. Selenium was then leached in sodium hydroxide. The recovery had reached $94 \%$ copper and $86.8 \%$ selenium. Other studies that are also conducted by Backstrom (2010) and Wang, Wesstrom and Fernandez (2003) to extract precious metals such as selenium and tellurium of anode slime which contains copper and nickel. In pressure oxidation leaching of copper anode slimes, more than $65 \%$ of the tellurium is coextracted during decopperizing. About $10-$ $15 \%$ of the selenium is also dissolved simultaneously by oxidation leach conditions.

Researchers also extracted precious metals from electronic waste as accomplished by Bigum, Brogaard and Christensen (2012). It is mentioned that the silver, gold, palladium and other metals could be extracted. Chen and Dutrizac (2004) examined gold separation from anode slime. It was that some of the gold was available as tiny metallic gold particles. The gold was associated with selenide particles that were soluble in the electrolyte of sulfuric acid due 
to the presence of chloride and thiourea. The copper separation will generate $\mathrm{Ag}-\mathrm{Au}$ selenide phase that is rich in gold and silver. Furtherly those elements can be separated.

As mentioned above, many typical routes of silver extraction from anode slimes have been determined by previous researchers. However, this paper only discusses the different process for extracting silver from anode slime through lead separation, followed by gold separation and continued by leaching with ammonia to produce the silver. The dechlorinated and chlorinated gold separating residues had been used as samples for the silver extraction to get the highest extraction recovery.

\section{METHODOLOGY}

In this study, the silver was separated from chlorination residues from anode slime after lead separation (Rodliyah et al., 2011, 2013). The extraction process is divided into two types namely:

chlorination residue was leached by ammonia at varying concentrations of 1 , 3,5 and $7 \mathrm{M}$; and dissolution temperatures of 30,40 and $60{ }^{\circ} \mathrm{C}$. The leaching residue was filtered and washed with dilute ammonia and the silver chloride was then evaporated by heating or blowing it with hot steam to diminish residual ammonia. The silver chloride was then dissolved in 6-M hot hydrochloric acid. A small amount of hydrogen peroxide was added into the material just before the end of the dissolution process. After that, deionized water was added to precipitate the silver chloride and then heated at $100{ }^{\circ} \mathrm{C}$ along with strong stirring. The next stage was adding sodium hydroxide to form silver oxide as well as supplementing dextrose or other reducing sugar to the slurry in terms of reducing silver oxide to metallic silver. This process took about 15 to 60 minutes. chlorination residues were dechlorinated by adding water to reach a concentration of $1000 \mathrm{~g} / \mathrm{L}$ along with the gradual addition of sodium carbonate to obtain a constant $\mathrm{pH}$ then it was filtered. The residue was washed by nitric acid to achieve $\mathrm{pH} 5$ and was cleaned by water. The residue was ready for silver extraction using the first procedure above. The flow diagram is shown in Figure1.

\section{RESULTS AND DISCUSSIONS}

Elemental composition of metals in anode slime can be seen in Table 1 . The table shows that lead has the highest content (63.90\%). Consequently, such a metal needs to be separated by dissolving it in an ammonia solution to get the valuable metals from the slime (Rodliyah et al., 2011). The second highest element content is selenium (4.97\%), followed by silver (4.25\%). Selenium is valuable when it is extracted from the anode slime. Other valuable elements such as gold have been extracted by Rodliyah et al. (2013) with the recovery of $99.99 \%$.

Table 1. Composition of anode slime

\begin{tabular}{lc}
\hline \multicolumn{1}{c}{ Element } & Content \\
\hline Gold $(\mathrm{Au})$ & $0.924 \%$ \\
Silver $(\mathrm{Ag})$ & $4.25 \%$ \\
Platinum (Pt) & $7.65 \mathrm{ppm}$ \\
Palladium (Pd) & $40 \mathrm{ppm}$ \\
Selenium (Se) & $4.97 \%$ \\
Lead (Pb) & $63.9 \%$ \\
Tellurium (Te) & $101 \mathrm{ppm}$ \\
Copper (Cu) & $0.28 \%$ \\
Iron (Fe) & $0.02 \%$ \\
\hline
\end{tabular}

Due to very high lead concentration in anode slime, extracting the lead will increase the concentration of the valuable element as analyzed by Atomic Absorption Spectrometry method and is shown in Table 2. The silver increases from 4.25 to $8.10 \%$, while the lead decreases from 63.90 to $22.00 \%$. However, the lead is still high and could be further separated by dechlorination process using sodium carbonate.

Table 2. Results of AAS analysis for lead leaching residue

\begin{tabular}{clc}
\hline No & \multicolumn{1}{c}{ Element } & Content \\
\hline 1 & Gold $(\mathrm{Au})$ & $1.61 \%$ \\
2 & Silver $(\mathrm{Ag})$ & $8.10 \%$ \\
3 & Lead $(\mathrm{Pb})$ & $22.00 \%$ \\
4 & Platina $(\mathrm{Pt})$ & $11 \mathrm{ppm}$ \\
5 & Palladium $(\mathrm{Pd})$ & $77 \mathrm{ppm}$ \\
\hline
\end{tabular}




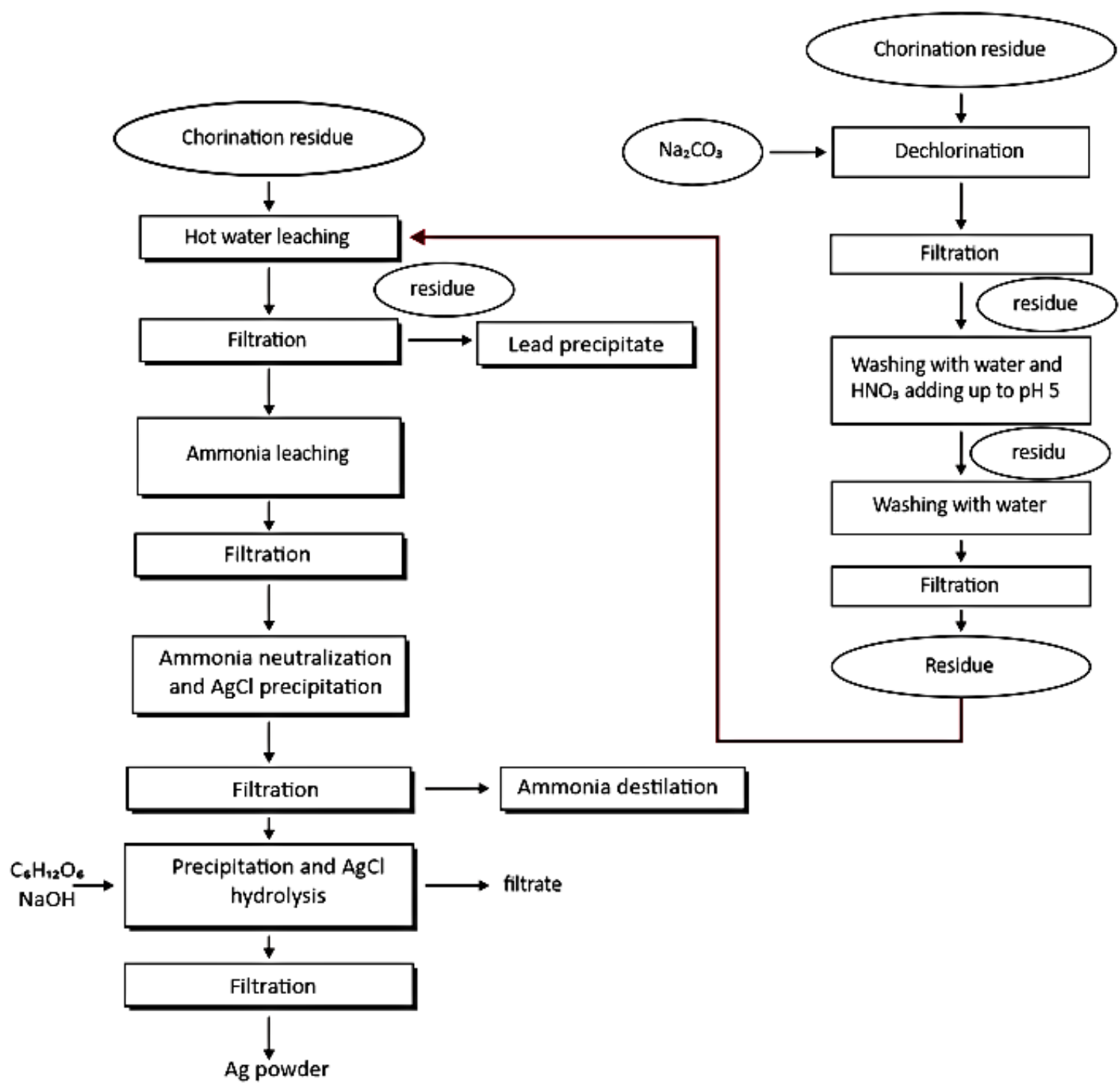

Figure 1. Flow diagram for silver extraction process

The XRD analysis of lead residue is shown in Table 3. The content is dominated by $33.94 \%$ downeyite $\left(\mathrm{SeO}_{2}\right), \quad 8.9 \%$ native selenium (Se) and other silver minerals such as $6.67 \%$ pavonite $\left(\mathrm{AgBi}_{3} \mathrm{~S}_{5}\right), \quad 6.22 \%$ acanthite $\left(\mathrm{Ag}_{2} \mathrm{~S}\right)$ and $5.42 \%$ fischesserite $\left(\mathrm{Ag}_{3} \mathrm{AuSe} \mathrm{S}_{2}\right)$. This result shows that the residue contains mostly silver and selenium.

The 1.61\%-gold (Table 2) facilitates gold extraction by wet chlorination process. The experiment was performed by adding $\mathrm{NaOCl}$ to get recovery of $98.86 \%$ gold. The chlorination residues were then used for extracting the silver. XRF analysis of chlorination residue shows more valuable elements (Table 4). It seems that the silver content reaches to $18.27 \%$. It significantly increases compare to the lead residues (Table 2). However, the lead slightly increases to $54.43 \%$. Selenium content reaches to $1.63 \%$. Such condition shows that the residue is ready for silver and selenium extraction. 
Table 3. Results of XRD analysis for lead leaching residue

\begin{tabular}{clcc}
\hline No. & \multicolumn{1}{c}{ Mineral } & Formula & $\begin{array}{c}\text { Content, } \\
(\%)\end{array}$ \\
\hline 1 & Anglesite & $\mathrm{PbSO}_{4}$ & 1.61 \\
2 & Fischesserite & $\mathrm{Ag}_{3} \mathrm{AuSe}_{2}$ & 5.42 \\
3 & Selenium & $\mathrm{Se}$ & 8.18 \\
4 & Rooseveltite & $\mathrm{BiAsO}_{4}$ & 2.87 \\
5 & Pavonite & $\mathrm{AgBi}_{3} \mathrm{~S}_{5}$ & 6.67 \\
6 & Bismite & $\mathrm{Bi}_{2} \mathrm{O}_{3}$ & 2.10 \\
7 & Acanthite & $\mathrm{Ag}_{2} \mathrm{~S}$ & 6.22 \\
8 & Downeyite & $\mathrm{SeO}_{2}$ & 33.94 \\
\hline
\end{tabular}

Table 4. Results of XRF analysis for chlorination residue

\begin{tabular}{clcc}
\hline No. & Compound/element & Formula & $\begin{array}{c}\text { Content, } \\
\%\end{array}$ \\
\hline 1 & Gold & $\mathrm{Au}$ & 0.47 \\
2 & Silver & $\mathrm{Ag}$ & 18.27 \\
3 & Lead & $\mathrm{Pb}$ & 54.43 \\
4 & Platinum & $\mathrm{Pt}$ & $<0.01$ \\
5 & Palladium & $\mathrm{Pd}$ & $<0.01$ \\
6 & Selenium & $\mathrm{Se}$ & 1.63 \\
7 & Arsenic oxide & $\mathrm{As}_{2} \mathrm{O}_{3}$ & $<0.01$ \\
8 & Bismuth oxide & $\mathrm{Bi}_{2} \mathrm{O}_{3}$ & $<0.01$ \\
9 & Rubidium oxide & $\mathrm{Rb}_{2} \mathrm{O}$ & $<0.01$ \\
10 & Antimony oxide & $\mathrm{Sb}_{2} \mathrm{O}_{3}$ & $<0.01$ \\
11 & Silicon dioxide & $\mathrm{SiO}_{2}$ & 0.92 \\
12 & Tin dioxide & $\mathrm{TiO}_{2}$ & 0.28 \\
13 & Tellurium oxide & $\mathrm{TeO}^{2}$ & 0.15 \\
14 & Zinc oxide & $\mathrm{ZnO}_{10}$ & 0.01 \\
15 & Chromium dioxide & $\mathrm{Cr}_{2} \mathrm{O}$ & 0.04 \\
16 & Copper oxide & $\mathrm{CuO}^{2}$ & 0.04 \\
17 & Nickel oxide & $\mathrm{NiO}$ & 0.02 \\
18 & Magnesium oxide & $\mathrm{MgO}$ & 0.40 \\
\hline
\end{tabular}

\section{Silver Extraction from Chlorination Residue}

Lead and gold separation yield silver containing residue that can be extracted for its silver using ammonium hydroxide solution. This process takes less than an hour. Its reaction is as follow:

$2 \mathrm{NH}_{4} \mathrm{OH} \rightarrow \mathrm{AgCl}+\left(\mathrm{Ag}\left(\mathrm{NH}_{3}\right)_{2}+\right)+\mathrm{Cl}+$ $2 \mathrm{H}_{2} \mathrm{O}$

The leaching slurry is then filtered and washed by dilute ammonia to release soluble silver salts from the slurry. Silver chloride is then heated or blown by hot steam to evaporate remaining ammonia. Evaporation reaction is:

$\left[\mathrm{Ag}\left(\mathrm{NH}_{3}\right)_{2}\right] \mathrm{Cl} \rightarrow \mathrm{AgCl}+2 \mathrm{NH}_{3}$
The silver chloride is then dissolved in $6 \mathrm{M}$ hot hydrochloric acid and a small amount of hydrogen peroxide is added just before the end of the dissolution process. At a concentration of 6-M hydrochloric acid, the chlorine gas can immediately be liberated and would tie up any gold or platinum group metals that might exist within silver chloride deposit. Leaching silver chloride is intended to separate the impurities elements that might be carried along with silver chloride and activated the silver chloride crystals hence the silver can react faster over the next reduction step.

Deionized water is added to precipitate silver chloride and heated at $100{ }^{\circ} \mathrm{C}$ along with intense stirring. The next step, sodium hydroxide is added to form silver hydroxide and then is dehydrated into silver oxide, following such a reaction:

$\mathrm{AgCl}+\mathrm{NaOH} \rightarrow \mathrm{NaCl}+\mathrm{AgOH}$

$2 \mathrm{AgOH} \rightarrow \mathrm{Ag}_{2} \mathrm{O}+\mathrm{H}_{2} \mathrm{O}$

Dextrose or other reducing sugar is added to the slurry to reduce the silver oxide into metallic silver. This reduction process occurs about 15 to 60 minutes through the reaction:

$12 \mathrm{Ag}_{2} \mathrm{O}+\mathrm{C}_{6} \mathrm{H}_{12} \mathrm{O}_{6} \rightarrow 6 \mathrm{CO}_{2}+6 \mathrm{H}_{2} \mathrm{O}+24 \mathrm{Ag}(5)$

Reactions (1) - (5) proved that the conducted experiments can extract silver from chlorination residue. The experiments were conducted by varying ammonia concentration and at different leaching time $(15,30,45$ and 60 minutes), temperature $\left(30^{\circ} \mathrm{C}\right)$, stirring speed $(100 \mathrm{rpm})$ and $\%$ solid (20). The result is shown in Figure 3.

Figure 2 shows the extracted silver and lead contents. It can be seen that after gold and lead separation, chlorination residue contains mostly silver chloride $(\mathrm{AgCl})$ and a little amount of lead chloride $\left(\mathrm{PbCl}_{2}\right)$. The experiment shows that the percentage of extracted silver increases with higher concentrations of ammonium hydroxide as well as leaching time. In relation to ammonium hydroxide concentration of $5 \mathrm{M}$ and $7 \mathrm{M}$, the silver extraction percentage is almost equal than that of the next trial that was set to the concentration of $5 \mathrm{M}$. 


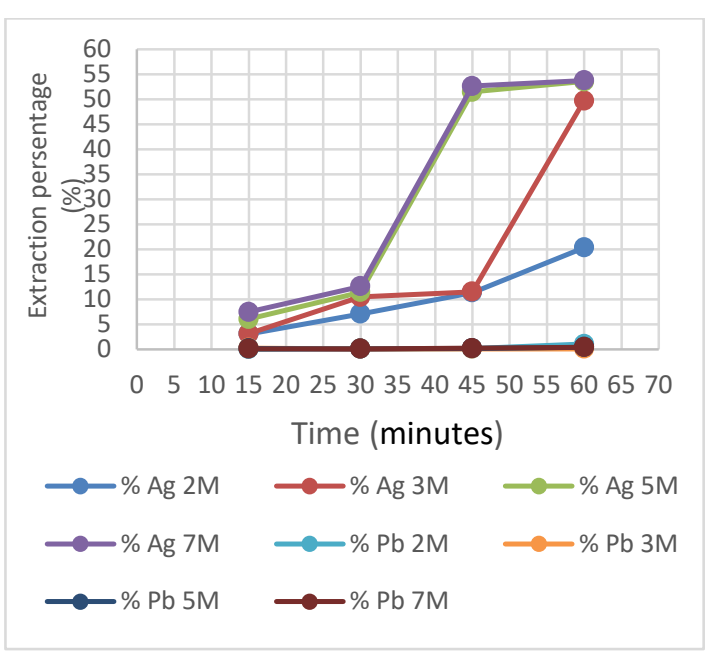

Figure 2. Silver extractions with varying concentrations (temperature $=30^{\circ} \mathrm{C}$, stirring speed $=100 \mathrm{rpm}$ and $\%$ solid $=20$ )

The next experiments were conducted to determine the effect of temperature on silver leaching. The result of the experiment can be seen in Figure 3.

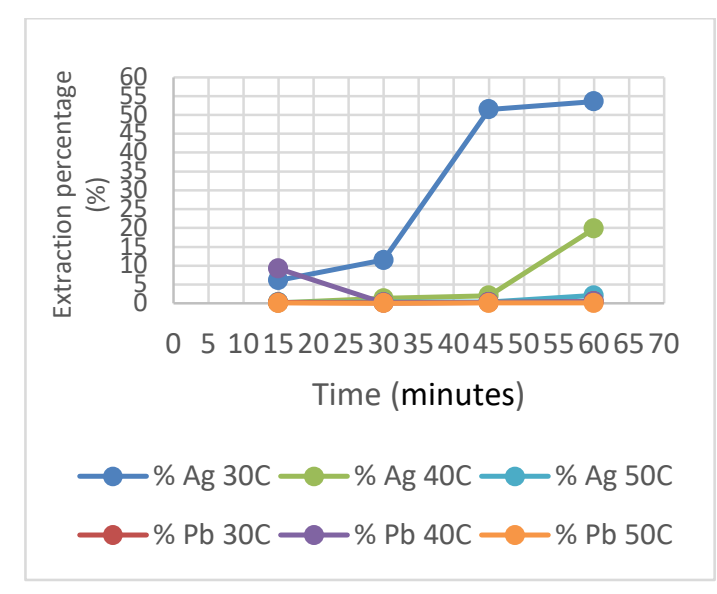

Figure 3. Extracted silver yielded from different temperatures and leaching times $\left(\mathrm{NH}_{4} \mathrm{OH}\right.$ concentrations: $5 \mathrm{M}$, stirring speed: $100 \mathrm{rpm}$ and \% solid: 20 )

It is assumed that that ammonia is the cause. It can be seen that if the leaching temperature increases, the percentage extracted silver decreases. It is assumed that ammonia evaporation is the cause, thus the ability of ammonium hydroxide in silver leaching from the residue declined. Ammonium hydroxide itself has a boiling temperature around $27^{\circ} \mathrm{C}$; therefore the heating experiment at $30^{\circ} \mathrm{C}$ is enough. However, increasing the temperature up to $40^{\circ} \mathrm{C}$ and $50^{\circ} \mathrm{C}$ would boil the solvent faster and decrease its ability to leach the silver from the residue. The best leaching time is 60 minutes as shown in Figure 3.

Considering the percentage of silver extraction that did not satisfy (only 53.56\%) results in requiring more trials. It is assumed that the available chlorides within residue have blocked the solvent to extract the silver. However, dechlorination process prior to the residue should be accomplished.

\section{Silver Extraction from Chlorination Residue Through Dechlorination Process}

As mentioned earlier that in silver extraction, silver and lead occurs in the form of silver chloride $(\mathrm{AgCl})$ and lead chloride $\left(\mathrm{PbCl}_{2}\right)$. Both of them are a solid form. Thus they remain within residue. To obtain optimum solubility of the silver, dechlorination of residues is required namely by adding sodium carbonate to form Ag-ammonium complex. Its solubility decreases rapidly with increasing concentration of chloride ion-free.

At first dechlorination process was accomplished by mixing chlorination residue within water with sodium carbonate gradually, to obtain a constant $\mathrm{pH}$. The purpose of mixing residue $\mathrm{Na}_{2} \mathrm{CO}_{3}$ is to get a concentration around $1000 \mathrm{~g} / \mathrm{L}$. This reaction is easy to be controlled by measuring the slurry $\mathrm{pH}$ through the sodium carbonate addition. The amount of required sodium carbonate can be estimated from its reaction stoichiometry between the lead chloride and the sodium carbonate. The reaction of the process is:

$\mathrm{PbCl}_{2}+\mathrm{Na}_{2} \mathrm{CO}_{3} \rightarrow \mathrm{PbCO}_{3}+2 \mathrm{NaCl}$

The lead sulfate within residue might also be carbonized as shown in reaction:

$\mathrm{PbSO}_{4}+\mathrm{Na}_{2} \mathrm{CO}_{3} \rightarrow \mathrm{PbCO}_{3}+\mathrm{Na}_{2} \mathrm{SO}_{4} \ldots . .(7)$

During the process, hydrocerussite $\left[\mathrm{Pb}_{3}\right.$ $\left(\mathrm{CO}_{3}\right)_{2}(\mathrm{OH})_{2}$ ] might also be formed as shown in reaction as follows:

$3 \mathrm{PbSO}_{4}+3 \mathrm{Na}_{2} \mathrm{CO}_{3}+\mathrm{H}_{2} \mathrm{O} \rightarrow\left[\mathrm{Pb}_{3}\right.$ $\left.\left(\mathrm{CO}_{3}\right)_{2}(\mathrm{OH})_{2}\right]+3 \mathrm{Na}_{2} \mathrm{SO}_{4}+\mathrm{CO}_{2}$ 
The difference of $\mathrm{PbCl}_{2}$ and $\mathrm{PbSO}_{4}$ solubility compared to that of $\mathrm{PbCO}_{3}$ is significant. Thus, conversion of $\mathrm{PbCl}_{2}$ and $\mathrm{PbSO}_{4}$ to form $\mathrm{PbCO}_{3}$ can completely take place. $\mathrm{AgCl}$ is less soluble than $\mathrm{Ag}_{2} \mathrm{CO}_{3}$, therefore, $\mathrm{AgCl}$ is unaffected by sodium carbonate leaching. Dechlorination process is intended mainly to separate the lead, thus the silver in the residue becomes more concentrated and does not interrupt the extraction process.

After lead separation, further experiments is silver extraction using 5-M ammonium hydroxide and leached for 60 minutes, at $30^{\circ} \mathrm{C}$. As expected, silver recovery increased to $95.60 \%$ and $94.30 \%$. The average of silver recovery is $94.95 \%$. The condition for dechlorination and its results is shown in Table 5.

Table 5. Silver recovery through dechlorination process

\begin{tabular}{llc}
\hline \multicolumn{2}{c}{ Leaching Condition } & \multicolumn{1}{c}{$\begin{array}{c}\text { Silver } \\
\text { Percentage (\%) }\end{array}$} \\
\hline$\left[\mathrm{NH}_{3}\right]$ & $: 5 \mathrm{M}$ & \\
Temperature & $: 30{ }^{\circ} \mathrm{C}$ & \\
Stirring speed & $: 100 \mathrm{rpm}$ & 95.60 \\
time & $: 60 \mathrm{~min}$. & 94.30 \\
$\%$ solid & $: 20$ & \\
\hline \multicolumn{2}{l}{} & Average: $94.95 \%$ \\
\hline
\end{tabular}

\section{CONCLUSIONS}

Since anode slime is a byproduct of copper refining that contains valuable metals such as silver, some experiments had been accomplished to extract lead, gold and silver. Extracting silver from chlorination residue obtained $53.56 \%$ recoveries.

In respect to the low recovery results, then some experiments were conducted through the residue dechlorination by adding sodium carbonate, followed by silver extraction to get higher recovery namely around $94.85 \%$. The residues were then leached by $5-\mathrm{M}$ ammonia and heated at $30{ }^{\circ} \mathrm{C}$ for 60 minutes.

Satisfied experiment results noted with high silver recovery present some advantages of this process such as short time leaching, low heating temperature and ammonium hydroxide usage that is easily available and reasonable. Therefore this process should be scaled up as well as conducted to a continuous system.

\section{ACKNOWLEDGEMENTS}

The authors would like to acknowledge PT Smelting Gresik for supplying the anode slime for the research. The authors would also like to show appreciation to the Ministry of Energy and Mineral Resources for research funding and also colleagues who involved in conducting the research.

\section{REFERENCES}

Aktas, S. (2010) "Silver recovery from spent silver oxide button cells," Hydrometallurgy, 104(1), pp. 106-111. doi: 10.1016/j.hydromet.2010.05.004.

Backstrom, J. (2010) Copper, nickel and tellurium yields during leaching of anode slimes. Lulea University of Technology.

Bard, G. N. and Sobral, and L. G. S. (2008) "Extraction of gold, silver and copper from the copper electrorefining anode slime: separation of the metals," in Mishra, B., Ludwig, C., and Das, S. (eds.) REWAS 2008 Global Symposium on Recycling, Waste Treatment and Clean Technology. Mexico: TMS (The mineral, Metals and Materials Society), pp. 142-148.

Bigum, M., Brogaard, L. and Christensen, T. H. (2012) "Metal recovery from high-grade WEEE: A life cycle assessment," Journal of Hazardous Materials, 207-208, pp. 814. doi: 10.1016/j.jhazmat.2011.10.001.

Chen, A., Peng, Z., Hwang, J.-Y., Ma, Y., Liu, X. and Chen, $X$. (2015) "Recovery of silver and gold from copper anode slimes," JOM, 67(2), pp. 493-502. doi: $10.1007 / \mathrm{s} 11837-014-1114-9$

Chen, T. T. and Dutrizac, J. E. (2004) "Gold in the electrorefining of copper and the decopperizing of copper anode slimes," JOM, 56(8), pp. 48-52. doi: 10.1007/s11837-004-0182-7.

Ernst Runyon G and E, H. J. (1972) "Recovery of silver from electrolytic copper refinery slimes." United State of America.

Hait, J., Jana, R. K., Kumar, V. and Sanyal, S. K. (2002) "Some studies on sulfuric acid leaching of anode slime with additives," Industrial \& Engineering Chemistry 
Research, 41(25), pp. 6593-6599. doi: 10.1021/ie020239j.

Hait, J., Jana, R. K. and Sanyal, S. K. (2009) "Processing of copper electrorefining anode slime: a review," Mineral Processing and Extractive Metallurgy, 118(4), pp. 240-252. doi: $10.1179 / 174328509 \times 431463$.

Harangi, Z., Kulcsar, T. and Kekesi, T. (2015) "Hydrometallurgical processing of anode slimes obtained from the electrolytic refining of soldering scrap," Materials Science and Engineering, 40(1), pp. 6474.

Kilic, Y., Kartal, G. and Timur, S. (2013) "An investigation of copper and selenium recovery from copper anode slimes," International Journal of Mineral Processing, 124, pp. 75-82. doi: 10.1016/j.minpro.2013.04.006.
Rodliyah, I., Ardha, N., Saleh, N. and Mubarok, Z. (2011) "Leaching the lead from anode slime by ammonium acetate solution," Indonesian Mining Journal, 14(3), pp. 123-132.

Rodliyah, I., Nuryadi Saleh, Ardha, N. and Mubarok, Z. (2013) "Effect of oxidizing agents in extracting gold from anode slime," Indonesian Mining Journal, 16(3), pp. 154-161.

Wang, S., Wesstrom, B. and Fernandez, J. (2003) "A novel process for recovery of Te and Se from copper slimes autoclave leach solution," Journal of Minerals and Materials Characterization and Engineering, 2(1), pp. 53-64. doi: 10.4236/jmmce.2003.21005.

Wang, W. K., Hoh, Y.-C., Chuang, W.-S. and Shaw, I.-S. (1981) "Hydrometallurgical process for recovering precious metals from anode slime." United State of America. 